\title{
Farmers' Knowledge, Perceptions and Management of Black Sigatoka in Small Plantain-Based Farms in Southern Benin
}

\author{
Fanou Alain Ahohouendo ${ }^{1, ~ *}$, Codjo Euloge Togbe ${ }^{1}$, Finagnon Robert Agbovoedo ${ }^{2,3}$, \\ Bonaventure Cohovi Ahohuendo ${ }^{1}$ \\ ${ }^{1}$ Faculty of Agricultural Sciences, University of Abomey-Calavi, Abomey-Calavi, Benin \\ ${ }^{2}$ Doctoral School of Agricultural and Water Sciences, University of Abomey-Calavi, Abomey-Calavi, Benin \\ ${ }^{3}$ Faculty of Agronomy, University of Parakou, Parakou, Benin
}

Email address:

a.f.ahohouendo@gmail.com (F. A. Ahohouendo)

${ }^{*}$ Corresponding author

\section{To cite this article:}

Fanou Alain Ahohouendo, Codjo Euloge Togbe, Finagnon Robert Agbovoedo, Bonaventure Cohovi Ahohuendo. Farmers' Knowledge, Perceptions and Management of Black Sigatoka in Small Plantain-Based Farms in Southern Benin. American Journal of Life Sciences. Vol. 8, No. 5, 2020, pp. 172-182. doi: 10.11648/j.ajls.20200805.23

Received: September 3, 2020; Accepted: September 22, 2020; Published: September 29, 2020

\begin{abstract}
Plantain (Musa paradisiaca) is a key crop, relevant to achieve food security and improve the livelihoods of many households in Africa, particularly in West Africa, where it has become a major staple food. But along with its production, farmers are facing a major foliar disease, the Black Sigatoka that limits the productivity. The yield losses incurred by farmers due to this disease can reach $50 \%$. Knowledge regarding this disease is crucial for effective management of the disease. This paper aims at diagnosing the differences in perceptions and knowledge between farmers and scientists with regard to strategies of managing black Sigatoka on plantain. A survey was conducted on 446 randomly selected farmers using a semi-structured questionnaire in five major plantain growing municipalities (Athiémé, Adja-Ouèrè, Tori-Bossito, Ouinhi, Zè) in Benin. This study came up with knowledge and perceptions of farmers on the symptoms, causes, conducive conditions for disease development, and means of dissemination and strategies for managing black Sigatoka. It appeared that most farmers recognized the disease lesions on the leaves, but failed to associate these symptoms with the targeted disease. In addition, farmers had very limited knowledge of the causal agent, disseminating mechanism and effective management methods. The majority of farmers that are aware of the symptoms (92.7\%) associated the yield loss on plantain field with the occurrence of this disease. This appreciation varied from a significant yield loss (54.2\%) to a moderate yield loss (45.8\%). Most farmers (69\%) did not adopt any disease control measures. Deleafing was the most common control method used by $30.2 \%$ of the farmers. Apart from this technique, very few farmers reported using synthetic pesticides and biopesticides based on neem leaves (Azadirachta indica). Agricultural research institutes and farmers' advisory systems were poorly involved in building and managing knowledge related to black Sigatoka in southern Benin. This study has the merit to bring out key information that will help design appropriate programme that would make it possible to manage this disease successfully in short and medium terms with smallholder farmers.
\end{abstract}

Keywords: Mycosphaerella fijiensis, Musa paradisiaca, Disease Management, Awareness

\section{Introduction}

Plantain is a major food crop in West and Central Africa [1] and ranks eighth among the global production of staple food crops. Plantain is widely produced in tropical and subtropical regions on small-scale farms. The fruit is mainly used for self-consumption and to meeting demands in local and regional markets [2]. Plantain is a great source of energy, and carbohydrates accounting for $32 \%$ of fruit weight. The fruit is rich in vitamins $\mathrm{A}, \mathrm{B} 6, \mathrm{C}$, minerals (calcium, iron and zinc) and dietary fibers. Based on this nutritional quality, plantain 
has been classified in Recommended Dietary Allowances (RDAs) of consumers [3, 4].

Under a monoculture system with no use of phytosanitary treatment and with optimal density of 1600 to 1650 plant/ha, average yields in West and Central Africa range between 5 and 12 tons per hectare $[5,6]$. Such a productivity is low given the plant's potential, which can go up to 20 and $30 \mathrm{t} / \mathrm{ha}$ on experimental stations under controlled and non-limiting growing conditions $[7,8]$. Pests have been identified as one of the main constraints leading to yield decrease [9]. In West Africa, main diseases and pests of plantain include black Sigatoka, weevils and nematodes [10, 11], but Banana bunchy top virus (BBTV) has mobilized much attention in recent years [12]. As far as diseases are concerned, black Sigatoka or black skate disease caused by the fungus Mycosphaerella fijiensis Morelet represents a great threat to banana and plantains [13]. This pathogen damages banana leaves causing necrotic leaf lesions that affect the photosynthetic capacity of the plants, resulting in yield reduction and poor quality of the fruit [14]. Yield losses of $20-50 \%$ was reported to be associated to this disease [15], and this can reach $100 \%$ for the following cropping cycle onwards [16]. The best strategy of managing this disease in industrial banana plantations has been a heavy application of broad-spectrum pesticides in the air during the whole production season [17]. In contrast, in most areas in West and Central Africa, dominated by plantations owned by household members [18], the level of maintenance of plantains still remains very low. These farmers have very limited knowledge on pests and pest outbreak and their effects on crops. As a result, very few farmers are involved in managing those constraints, including black Sigatoka [19].

In Benin, plantain is mainly cultivated in agro-ecological zones 6, 7 and 8, which offer suitable conditions to banana production compared to other regions of the country [20]. In recent years, plantain-based foods have gradually become part of the diet habits of population; as a result, production has increased, as well as acreage allocated. It has been reported since 2012 the presence of black Sigatoka as the main constraint to plantain production is Benin. Also, this disease was pointed out largely to be responsible for significant yield losses and a reduction in the life cycle of plantations [21]. Therefore, managing this disease has become a challenge to farmers since no scientific work has not been conducted targeting this disease in Benin. Also, consistent training was not organized on behalf of farmers with respect to the disease. In this regard, it appears very useful to assess the knowledge of farmers and their practices toward the management of black Sigatoka [22, 23]. The output of this investigation is likely to be used as input to design a training programme in order to facilitate an uptake of innovations developed to address this disease. Such information is also important for extension workers and policy makers [24] to develop relevant advisory programme. Moreover, it is widely acknowledged that economies of African countries are largely based on small-scale farmers for whom the integration of endogenous knowledge is vital in the development and introduction of new technologies at the local level $[25,26]$. In fact, in order to address effectively challenges regarding pest management, the needs of farmers in terms of knowledge and information should be well identified [25]. But, all over the world, knowledge and perceptions of farmers about black Sikatoga and its effective management are very limited [27, 30]. The existing knowledge gap makes it possible to question the performance of crop disease management methods. Therefore, it appears essential to investigate farmers current knowledge, perceptions and management methods in order to establish a relevant programme for the management of black Sigatoka in small scale farms in southern Benin. This aims at filling the gap, while assessing the contribution of this knowledge to the development of good agricultural practices leading to better prevention and control of this disease. This research will be guided by three research questions:

(1) What are the knowledge and perceptions of farmers on black Sigatoka and disease management?

(2) Does the knowledge of farmers on the symptoms of the disease relate to their socio-demographic characteristics?

(3) What relationship could we establish between farmers' knowledge and disease management methods?

\section{Methodology}

\subsection{Study Area}

The survey was conducted in the southern Benin, located in the Guinean sub-humid zone, between $6^{\circ} 25^{\prime}$ and $7^{\circ} 30^{\prime} \mathrm{N}$. The climate is sub-equatorial with two dry seasons and two rainy seasons. The average annual temperature varies between $25^{\circ}$ and $29^{\circ} \mathrm{C}$ and the relative humidity between 69 and $97 \%$.

The early vegetation consists of dense semi-deciduous forests and Guinean savannas [31]. The environment offers suitable climatic and edaphic conditions for plantain production. Five major plantain-producing municipalities were identified based on an exploratory study carried out as part of the Avlanto-Benin project activities; three belonging to "Agence Territorial de Développement Agricole" (ATDA 7): Athiémé, Tori-Bossito and Zè; while one to ATDA 6: Adja-Ouèrè, and the last one to ATDA 5: Ouinhi (Figure 1).

\subsection{Sampling Method}

The sample size $n_{i}$ for each municipality is calculated from the [32] formula.

$$
n_{i}=e z^{2} p_{i}\left(1-p_{i}\right) / t d^{2}
$$

with:

1) $n_{i}$, the minimum size of the sample of farmers to be selected in the municipality $\mathrm{i}$ in order to be able to generalize the outcomes;

2) $e$, the cluster effect set at 1.5 ;

3) $z$, the value of $95 \%$ confidence level which is 1.96 according to the standard normal distribution;

4) $p_{i}$, the weight of farmers with regard to farmers and 
ancillaries within municipality i;

5) $t$, the response rate, generally $98 \%$ for agricultural surveys;

6) $d$, the error margin set at $3 \%$.

The fourth General Census of Population and Housing (GCPH-4) carried out in 2013 was used to determine the parameter $p_{i}$. The following formula was used to estimate farmers' population in 2019.

$$
\operatorname{Pop}_{n}=\operatorname{Pop}_{0}(1+t)^{n}
$$

with:

$P_{o p_{n}}$ : Population for year $\mathrm{n} ; P_{o p_{0}}$ : Population for the reference year; $t$ : Population growth rate and $n$ : Difference between the target year and the reference year.

Table 1. Distribution of surveyed farmers per municipality.

\begin{tabular}{|c|c|c|c|c|c|c|}
\hline Municipality & Farmers population (2013) & Rate of growth (\%) & $\begin{array}{l}\text { Farmers population } \\
(2019)\end{array}$ & $\begin{array}{l}\text { Plantain farmers population } \\
\text { (2019) }\end{array}$ & $p_{i}$ & $n_{i}$ \\
\hline Tori-Bossito & 32194 & 5.1 & 43266 & 585 & 0.0135 & 93 \\
\hline Zè & 67941 & 5.1 & 91308 & 990 & 0.0108 & 75 \\
\hline Athiémé & 27733 & 2.9 & 32922 & 1029 & 0.0313 & 211 \\
\hline Adja-Ouèrè & 66801 & 3.8 & 83699 & 523 & 0.0062 & 43 \\
\hline Ouinhi & 42691 & 3.2 & 51422 & 176 & 0.0034 & 24 \\
\hline Total & 237360 & & 302618 & 3303 & - & 446 \\
\hline
\end{tabular}

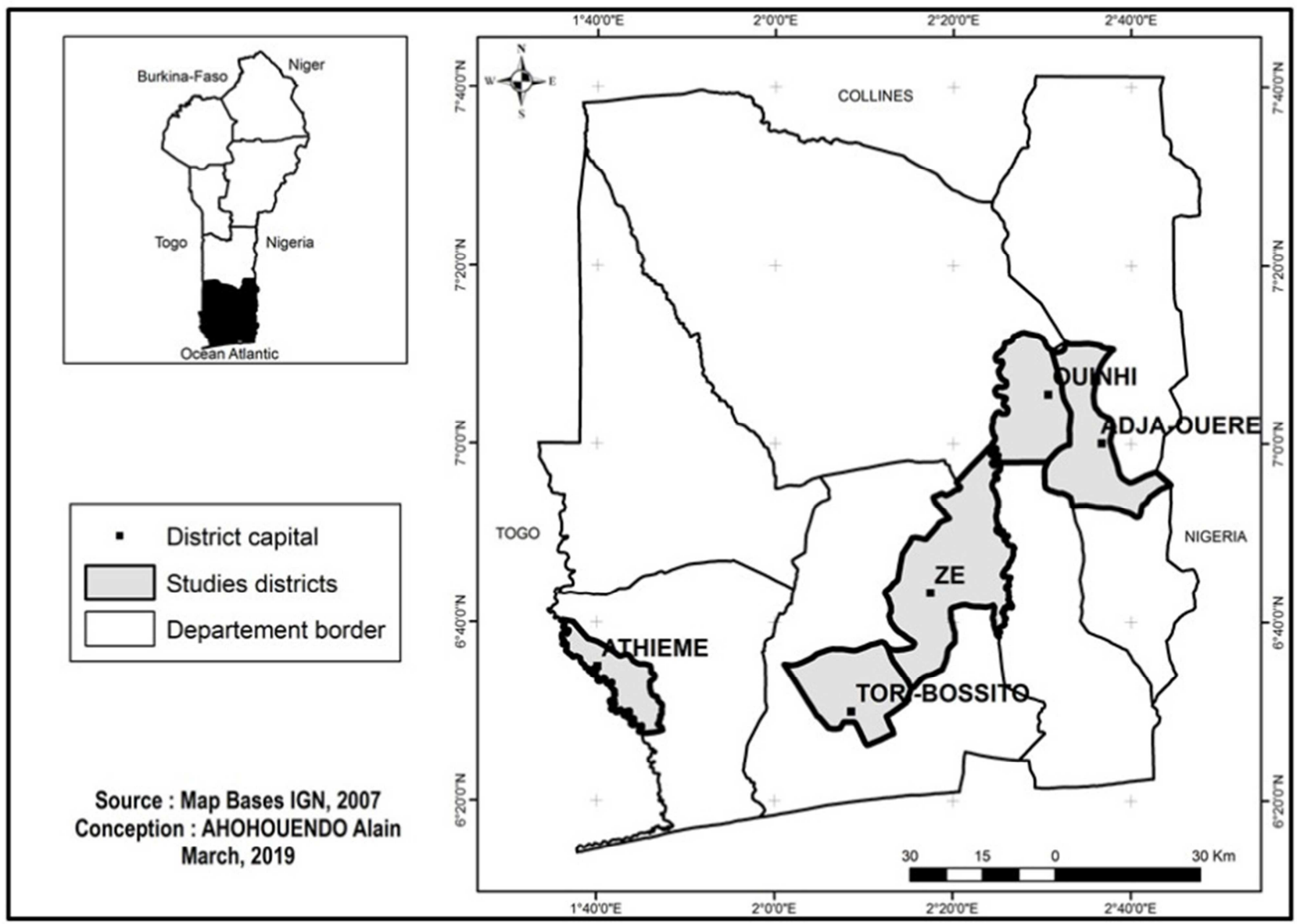

Figure 1. Study area showing the municipalities of Adja-Ouèrè, Athiémé, Ouinhi, Tori-Bossito and Zè.

\subsection{Data Collection and Analysis}

Data was collected from plantain farmers from September to November 2019 using direct individual interviews based on structured and semi-structured questionnaires. Those data include socio-demographic characteristics of participants (gender, age, education level, main activity, socio linguistic group, number of years of experience in plantain), knowledge of symptoms, cause, suitable conditions for development, and means of dissemination of disease and management methods. Colored photographs showing foliar symptoms of black Sigatoka was also used to sustain the questionnaires. Farmers of 5 years' experience in plantain production were identified with the assistance of local authorities using the "snowball" sampling method, which is a chain sampling method consisting of targeting other participants based on the commendations of the previous ones [33]. Data were analyzed using descriptive 
statistics. Proportions of variable modalities were calculated with a proportion test. In addition, the Fisher's exact test was performed to assess the independence of the different variables crossed with each municipality. These analyses were carried out using the $\mathrm{R}$ program [34], version 4.0.0. The level of significance was set at the $5 \%$ threshold. The various graphs were generated using the ggplot2 package [35].

\section{Results}

\subsection{Socio-demographic Characteristics of Farmers}

Out of the 446 farmers surveyed for the study, $86.1 \%$ were men. The main activity of the majority of farmers (93.3\%) was agriculture. The average age of participants was $42.66 \pm$ 10.5 years, with many farmers $(66 \%)$ between 30 and 60 years of age. The majority of respondents $(84 \%)$ were from the socio-linguistic group "fon", followed by the "adja" (13\%) and the "yoruba" (3\%). About 49\% of farmers did not receive any formal education. The remaining belong to various education levels: $26 \%$ at the primary level, $16 \%$ at the higher education level and $1.7 \%$ at the college level, while the other $6.3 \%$ were just literate. Number of experience years is determinant in plantain production. In fact, $16.4 \%$ of farmers had over 20 years experience while $41.0 \%$ of them had between 10 and 20 years in plantain production.

\subsection{Knowledge of Farmers on Black Sigatoka Symptoms and Socio-demographic Characteristics}

Farmers' knowledge on the symptoms of black Sigatoka was very strongly influenced by gender, age, socio-linguistic group, education level, municipality and years of experience in plantain production with a very highly significant difference $(p<0.0001$; Table 2$)$. In fact, all the women involved in this study against $84.3 \%$ of men had the ability to recognize black Sigatoka leaf lesions in their plantation. In addition, the majority of farmers who easily recognized leaf lesions in their plantation were between 30 and 60 years old. The presence of leaf lesions was recognized by all farmers belonging to the "Yoruba" socio-linguistic group and respectively by $98.3 \%$ and $98.1 \%$ of the "Adja" and "Fon". Similarly, leave lesions were identified by all farmers in the municipalities of Adja-Ouèrè, Ouinhi and Tori-Bossito and by $98.6 \%$ and $93.3 \%$ of farmers in Athiémé and Zè, respectively. The level of education proved to be a favourable factor in lesion identification. In fact, leaf lesions were recognized by all participants with a level of education equal to or higher than upper secondary school.

Table 2. Knowledge of leaf lesions according to socio-demographic characteristics.

\begin{tabular}{|c|c|c|c|c|}
\hline \multirow{2}{*}{ Characteristic } & \multicolumn{2}{|c|}{ Leaf lesions } & \multirow{2}{*}{ Size $(n=446)$} & \multirow{2}{*}{ p-value (prop. test) } \\
\hline & - & + & & \\
\hline \multicolumn{5}{|l|}{ Municipalities } \\
\hline Adja-Ouèrè & 0 & 42 & 42 & \multirow{5}{*}{$<0.0001$} \\
\hline Athiémé & 3 & 208 & 211 & \\
\hline Ouinhi & 0 & 25 & 25 & \\
\hline Tori-Bossito & 0 & 93 & 93 & \\
\hline Zê & 5 & 70 & 75 & \\
\hline \multicolumn{5}{|l|}{ Sex } \\
\hline Female & 0 & 62 & 62 & \multirow{2}{*}{$<0.0001$} \\
\hline Male & 8 & 376 & 384 & \\
\hline \multicolumn{5}{|l|}{ Age } \\
\hline Young (18-29 years old) & 1 & 36 & 37 & \multirow{3}{*}{$<0.0001$} \\
\hline Adult (30-60 years old) & 2 & 293 & 295 & \\
\hline Old (plus de 60 years old) & 5 & 109 & 114 & \\
\hline \multicolumn{5}{|l|}{ Socio-linguistic groups } \\
\hline Adja & 1 & 57 & 58 & \multirow{3}{*}{$<0.0001$} \\
\hline Fon & 7 & 368 & 375 & \\
\hline Yoruba & 0 & 13 & 13 & \\
\hline \multicolumn{5}{|l|}{ Educational level } \\
\hline No formal education & 3 & 216 & 219 & \multirow{6}{*}{$<0.0001$} \\
\hline Literacy & 1 & 31 & 32 & \\
\hline Primary & 3 & 113 & 116 & \\
\hline Secondary 1 st cycle & 2 & 51 & 53 & \\
\hline Secondary $2^{\text {nd }}$ cycle & 0 & 18 & 18 & \\
\hline Higher education & 0 & 8 & 8 & \\
\hline \multicolumn{5}{|l|}{ Primary activity } \\
\hline Farmer & 8 & 408 & 416 & \multirow{4}{*}{$<0.0001$} \\
\hline Artisan & 0 & 9 & 9 & \\
\hline Trader & 0 & 16 & 16 & \\
\hline Civil servant & 0 & 5 & 5 & \\
\hline \multicolumn{5}{|l|}{ Production experience years } \\
\hline $5-10$ & 4 & 186 & 190 & \multirow{3}{*}{$<0.0001$} \\
\hline $10-20$ & 0 & 183 & 183 & \\
\hline$>20$ & 4 & 69 & 73 & \\
\hline
\end{tabular}

$(+)$ knowledge and (-) non-knowledge of leaf lesions of black Sigatoka 


\subsection{Farmers' Knowledge and Perceptions on Leaf Lesions and Appearance Period}

Farmers' knowledge of the period of leaf lesion appearance varied from one municipality to another $(\mathrm{p}=0.02$; Table 3$)$. For the majority of farmers $(68 \%)$, lesions were more likely to be observed on leaves during the dry season, while for $24.2 \%$ of farmers, leaves were subject to black Sigatoka lesions throughout the year. Only $7.8 \%$ of farmers indicated that leaf lesions appeared in their plantation only in the wet season (Figure 2A). Farmers' perception of the presence of leaf lesions was diversely appreciated and varied from municipality to municipality ( $\mathrm{p}=0.03$; Table 3 ). According to
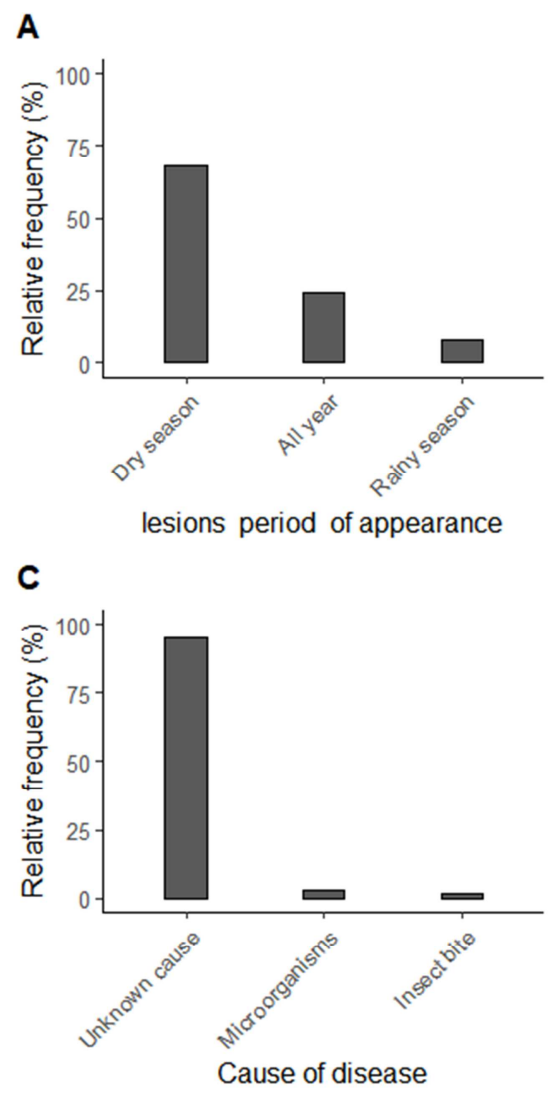

Figure 2. Farmer's knowledge on (A) the period of appearance of leaf lesions; (B) the cause of leaf lesions; (C) the cause of the disease and (D) the effect of the disease on yield.

\subsection{Farmers' Knowledge on the Black Sigatoka Causal Agent and Effects of the Disease on Crop Yield}

Farmers' level of knowledge on the causal agent of black Sigatoka did not vary from one municipality to another $(p=0.07$; Table 3$)$. In general, very few farmers $(3.4 \%)$ had knowledge of the causal agent of Sigatoka. They indicated that this disease was caused by microorganisms (Figure 2C). This showed that $94.9 \%$ of the farmers have no knowledge of the cause of the disease, of which $1.8 \%$ equated it to insect bites. Farmers having knowledge of the causal agent were among those who associated leaf lesions to a disease; their education level corresponded to at least lower secondary
$91.1 \%$ of farmers, environmental and biological factors were responsible for the development of leaf lesions. Those factors included water scarcity $(59.1 \%)$, sunburn (15.8\%), soil poverty $(8.9 \%)$, insect attacks $(5.9 \%)$ and soil water saturation (1.4\%) (Figure 2B). Farmers who equated leaf lesions to water scarcity indicated that leaves were naturally necrotic under water stress. Only $8.9 \%$ of farmers identified leaf lesions as a disease, they were not able to name it (Figure 2B). Most of these farmers (95\%) had at least a junior high school education and have received this information from a formal farmer advisory organization.

B

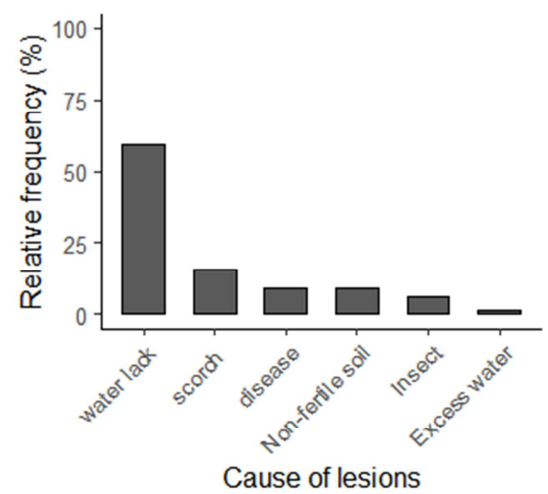

D

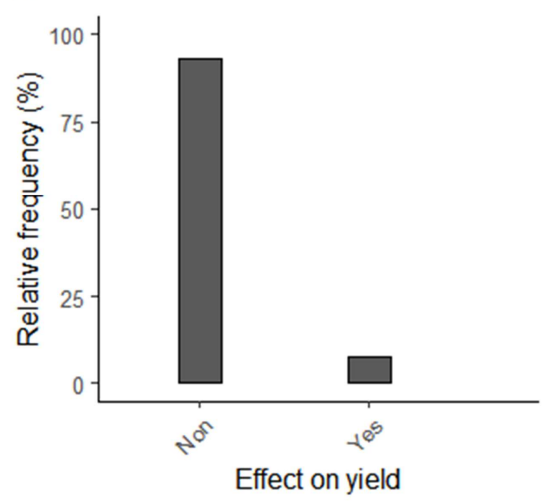

school and received this information from a formal agricultural advisory organization. However, none of the farmers had any idea about the mechanism of propagation, preservation and transmission of the pathogen.

All farmers having knowledge of the symptoms of black Sigatoka reported a decrease in yields in their respective fields (Figures 2D and 3A). Analysis of these figures revealed that the majority of these farmers (92.7\%) associated this yield decrease with black Sigatoka, without giving an explanation for the decrease in photosynthetic activity caused by leaf lesions. Farmers' assessments of yield varied significantly from one municipality to another $(\mathrm{p}=<$ 0.0001 ; Table 3 ). For the majority of farmers, black Sigatoka 
significantly (54.2\%) and moderately $(26.6 \%)$ reduced plantain fruit size, while for $11.6 \%$ and $2.7 \%$ of farmers, black Sigatoka had little and very little effect on plantain yield, respectively.

\subsection{Farmers' Methods of Managing Black Sigatoka}

Methods of managing disease did not differ from one municipality to another. In fact, no significant difference $(p=0.21$; Table 3 ) was noted between the municipalities with regard to the control methods adopted by farmers. The majority of farmers $(82.8 \%)$ who reported symptoms of black
Sigatoka in their plantain fields did not adopt any specific method to managing the disease; leaf stripping, which is a cultural method of disease management, was adopted by only $12.6 \%$ of farmers (Figure 3B). Chemical control and biological/endogenous control were practiced respectively by $2.6 \%$ and $2 \%$ of farmers (Figure $3 \mathrm{~B}$ ). The synthetic products were those recommended in cotton production, banana and plantain monoculture. Aqueous solution and neem leaf aqueous extracts (Azadirachta indica) are the organic/endogenous products adopted by some farmer.

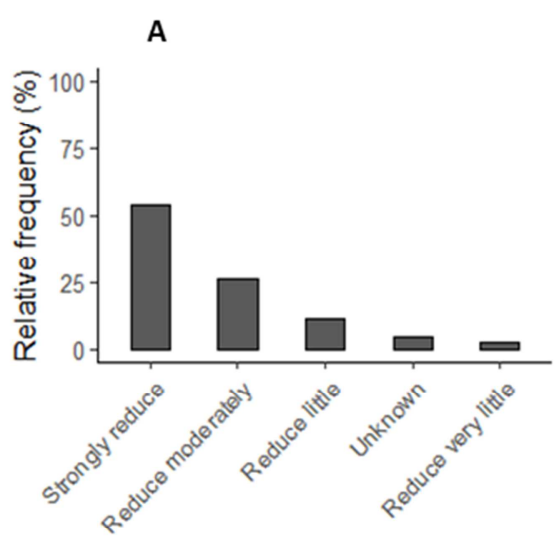

Effect on fruit size

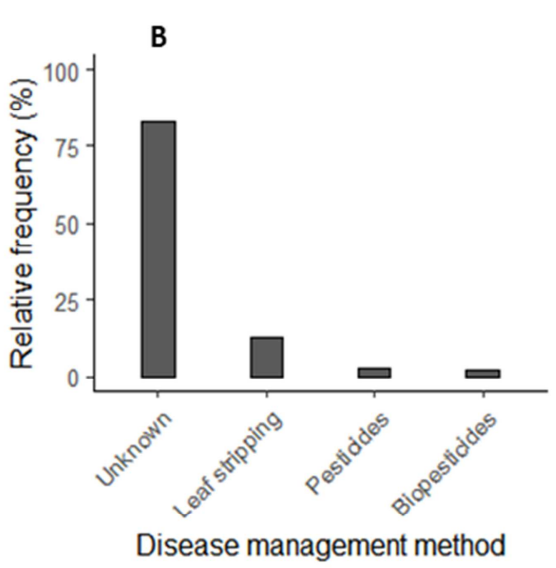

Disease management method

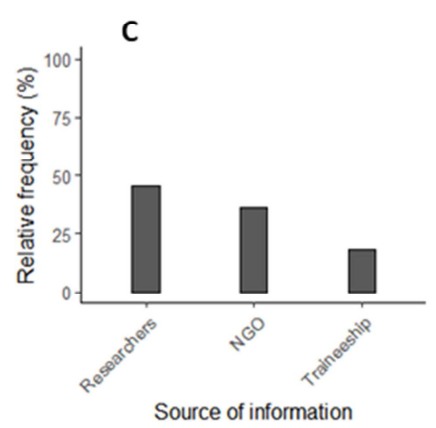

Figure 3. Farmers' knowledge of (A) the effect of the disease on fruit size (B) control methods; (C) the organs involved in the management of the disease.

\subsection{Agricultural Organizations' Involvement in Knowledge and Management of Black Sigatoka}

Support from farmer's advisory system was not generalized to all farmers involved in this study. In fact, out of the 446 farmers surveyed, only 11 farmers $(2.5 \%)$ received information on black Sigatoka at least once from agricultural organizations represented by researchers from universities, agricultural research centers (INRAB) and NGOs (Figure 3C). According those farmers, the information concerned two improved varieties (FHIA 21 and Pita 3), resistant to black Sigatoka introduced in Benin between 2012 and 2016. These varieties were massively distributed to farmers in some municipalities in southern Benin within the framework of West African Agricultural Productivity Programme (WAAPP) coordinated by the West and Central African Council for Agricultural Research and Development (WECARD). However, these introduced varieties were left out by farmers in favour of local varieties.

Table 3. Distribution (\%) of plantain farmers according to knowledge of black Sigatoka in the five study municipalities.

\begin{tabular}{|c|c|c|c|c|c|c|c|}
\hline Variables & Modality & $\begin{array}{l}\text { Adja-Ouèrè } \\
(n=43)\end{array}$ & $\begin{array}{l}\text { Athiémé } \\
(n=211)\end{array}$ & $\begin{array}{l}\text { Ouinhi } \\
(n=24)\end{array}$ & $\begin{array}{l}\text { Tori-Bossito } \\
(\mathrm{n}=93)\end{array}$ & $\begin{array}{l}\text { Zè } \\
(n=75)\end{array}$ & p-value \\
\hline \multirow{3}{*}{$\begin{array}{l}\text { Lesions period } \\
\text { appearance }\end{array}$} & Rainy season & 0 & 2.5 & 0.2 & 2.5 & 2.5 & \multirow{3}{*}{0.02} \\
\hline & Dry season & 8 & 40 & 3.9 & 3.4 & 12.8 & \\
\hline & Throughout the year & 1.6 & 5.0 & 1.6 & 15.3 & 0.7 & \\
\hline Lesions farmer & Insect & 0.2 & 2.5 & 0 & 0.5 & 2.7 & 0.03 \\
\hline
\end{tabular}




\begin{tabular}{|c|c|c|c|c|c|c|c|}
\hline Variables & Modality & $\begin{array}{l}\text { Adja-Ouèrè } \\
(n=43)\end{array}$ & $\begin{array}{l}\text { Athiémé } \\
(\mathrm{n}=211)\end{array}$ & $\begin{array}{l}\text { Ouinhi } \\
(n=24)\end{array}$ & $\begin{array}{l}\text { Tori-Bossito } \\
(\mathrm{n}=93)\end{array}$ & $\begin{array}{l}\text { Zè } \\
(n=75)\end{array}$ & p-value \\
\hline \multirow[t]{6}{*}{ perceptions } & Sun burns & 0.7 & 7.1 & 0.5 & 5.9 & 1.6 & \\
\hline & Excess water & 0 & 0.7 & 0 & 0 & 0.7 & \\
\hline & Disease & 1.6 & 2.5 & 1.6 & 2.5 & 0.7 & \\
\hline & Lack water & 7.1 & 32.2 & 3.7 & 6.4 & 9.8 & \\
\hline & Non-fertile soil & 0 & 2.5 & 0 & 5.9 & 0.5 & \\
\hline & Unknown cause & 8.1 & 46.1 & 4.3 & 20.4 & 16.1 & \\
\hline \multirow{3}{*}{ Cause of disease } & Insect bite & 0 & 0.7 & 0.2 & 0.2 & 0.7 & \\
\hline & Unknown & 0 & 4.9 & 0 & 0 & 0 & \\
\hline & High reduction & 7.6 & 25.4 & 3.2 & 2.7 & 15.3 & \\
\hline \multirow[t]{4}{*}{ Effect on fruit size } & Moderate reduction & 1.5 & 15.5 & 2.7 & 6.9 & 0 & $<0 \Omega 0 \cap 1$ \\
\hline & Little reduction & 0.2 & 3.4 & 0 & 7.9 & 0 & $<0.0001$ \\
\hline & Very little Reduction & 0 & 0 & 0 & 2.7 & 0 & \\
\hline & Unknown & 8 & 29.5 & 4.9 & 24.6 & 15.8 & \\
\hline \multirow{2}{*}{ Methods'management } & Biopesticides & 0.3 & 0.6 & 0.3 & 0 & 0.9 & 0.21 \\
\hline & Deleafing & 3.7 & 2.3 & 2.0 & 1.4 & 3.2 & \\
\hline \multirow{3}{*}{$\begin{array}{l}\text { Support from Farmer } \\
\text { Advirory System }\end{array}$} & Researchers & 9.1 & 0 & 36.4 & 0 & 0 & \\
\hline & NGO & 9.1 & 0 & 27.3 & 0 & 0 & 0.61 \\
\hline & Traineeship & 9.1 & 0 & 0 & 0 & 9.1 & \\
\hline
\end{tabular}

\section{Discussion}

This paper investigated farmers' knowledge and perceptions of the main plantain foliar disease and its management methods.

\subsection{Farmer's Knowledge and Perceptions on Black Sigatoka}

Overall, it was found that plantain farmers had limited knowledge on black Sigatoka compared to the available scientific information on the disease. Most farmers were able to recognize and describe the symptoms of black Sigatoka in their fields. Strategies to control this disease varied according to socio-demographic characteristics such as gender, age, ethnicity, and education level, municipality of origin and respondent's experience in plantain production. However, very few of farmers equated these symptoms with disease. Rather, those symptoms were considered as manifestations of various environmental and biological effects. The inability of plantain farmers in southern Benin to indicate leaf lesions as symptoms of black Sigatoka may be linked to the lack of advisory system related to banana in general and plantain in particular. Indeed, in Benin, bananas and plantains have not been included in the priority sectors of the "Plan Stratégique de Développement Agricole", which is benefiting from consistent monitoring and support from the state. As a result, despite the enthusiasm of farmers and consumers, plantain has remained a poorly promoted crop by the government. As a result, the crop has not been well organized. These results suggest the need of involving extension services in the knowledge and management of black Sigatoka. This was confirmed in the current study, as only $2.5 \%$ of the farmers had heard about black Sigatoka from either researchers, NGOs or extension services without having participated in formal training on the knowledge and management of plantain diseases. Similar observations were made by Tafesse et al., who demonstrated that most farmers in Ethiopia can easily recognize and describe the symptoms of the major potato diseases such as late blight and brown rot, but have difficulty associating them with a disease [23]. In addition, Echodu et al., showed in four East African countries that sweet potato farmers could not associate symptoms of diseases such as leaf wilt, leaf curling and yellowing with viral, bacterial or fungal diseases, which were generally perceived as manifestations of leaf senescence, drought or excess water [30].

According to the majority of farmers $(68 \%)$, the period of high disease pressure with highly visible symptoms was during the dry season. This result is surprising because seasonal trends in disease development are high in hot and humid weather; and followed by higher production of conidia and ascospores [36]. This suitable period for disease development corresponds to the two rainy seasons in southern Benin. This result is quite different to the normal trend and can be explained by confusion with farmers between leaf lesions due to black Sigatoka and those of leaf senescence recorded in the dry season. On the other hand, it should be noted that Benin's climates have experienced disturbances in recent decades [37] that could favour the appearance of leaf lesions in the dry season. As a result Ahanger et al., considered that climate variability affects all stages of the life cycle of a pathogen and the host and clearly raise the challenge of pathosystem control [38].

Concerning the causal agent of black Sigatoka, no farmer was able to explain the dissemination and dispersal mechanisms. Whereas, according to Rieux et al., and Robert et al., the pathogen can be dispersed naturally by rainwater or wind over short distances at plot scale or from one plantation to another $[39,40]$. On the other hand, frequent long-distance (up to several kilometers) ascospore movement by wind dispersal has been suspected previously in this species [41]. Over long distances, the dissemination of the pathogen occurs also through exchanges between farmers of 
contaminated planting material on a national scale or beyond. Since the pathogen is primarily aerial and disperses largely by wind, farmers need to be aware of the mechanism and adopt good practices inoculum reduction at regional scale. This suggests farmers to master the dissemination mechanism of the causal agent. The current results were confirmed by Islam et al., who found out that one of the key factors affecting many farmers in low-income countries is their lack of knowledge on the dissemination mechanisms of pests and diseases [42]. For example, Uwamahoro et al., studied farmers' knowledge of potato brown rot in Rwanda and found out that less than half of the respondents knew that the causal agent spreads through infected soil, tubers, seeds and the use of infected farming tools [29].

Despite the lack of knowledge on black Sigatoka, most farmers $(92.7 \%)$ recognized the negative effect of leaf lesions on plantain yield. These results show that black Sigatoka is a threat to small plantain farmers in southern Benin. However, farmers were not able to quantify the real losses caused by this disease in their plantations. This trend reinforces the difficulties in estimating yield losses caused by plant pests and diseases. Savary et al., considered that, theoretically, the yield loss margins generally used do not correctly reflect the real costs of losses to stakeholders in a value chain. This is due to other complex elements that come into play such as post-harvest quality losses and the possible accumulation of toxins during and after the growing season [43].

\subsection{Management Practices for Black Sigatoka}

The majority of farmers $(69 \%)$ did not developed any method to control black Sigatoka in their fields. The main reason was the lack of information on this disease and the lack of organization in the plantain value chain. According to the work of Pérez-Vicente, in order to be effective, the management strategy for black Sigatoka must focus on eliminating or reducing the pressure of the disease inoculum, so that management must be organized at the scale of the areas (which may include several farmers or communities) through mechanisms or measures accessible to the communities [36]. However, the dominant management practice reported by the farmers was the deleafing, adopted by $30.2 \%$ of the farmers, who recognized the effectiveness of this practice but contended that deleafing contributes to the reduction of fruit weight. However, according to PérezVicente, deleafing is only effective in controlling the disease when it is combined with other cultural practices [36], such as canopy irrigation [44] and good fertilization to strengthen the plant's defense system [7]. To address successfully black Sigatoka disease, the use of hybrid resistant varieties has been widely promoted by researchers in African countries suitable to plantain production [45-47]. Although these varieties, in particular Pita 3 and FHIA 21, were introduced in Benin through the National Institute of Agricultural Research [45], but no farmers have adopted this control method. This can be explained by the fact that these farmers are very attached to locally produced cultivars. According to Quain et al., the adoption of a new variety by farmers and its acceptability to consumers is based on various preferences, including taste, consistency and cook ability [48]. However, Cavero et al., reported that the use of disease-resistant hybrid varieties is far from being sustainable because of factors such as the narrow genetic base of plantain and the variability of the pathogen, which could rapidly adapt to new resistance genes due to its sexual reproduction [49].

This study also revealed that few farmers have adopted control strategies using synthetic pesticides and biopesticides. According to respondents, plantain has traditionally been produced on small scale farms in Benin without specific inputs. This result was found by Traoré et al., who indicated that the level of maintenance in plantain fields remains low in West and Central Africa [19]. As a result, the percentage of farmers carrying out phytosanitary control of black cercosporiose in peasant farming is very low. However, this method is more adopted in industrial plantations with regular aerial applications of broad-spectrum pesticides [50]. But, it is highly criticized because it negatively affects the environment [51] with side-effects of increased resistance of the strains of the causal agent $[46,52]$ and increase in treatment costs estimated at over $25 \%$ of the production cost [53].

\section{Conclusion and Policy Recommendations}

This study assessed the knowledge and perceptions of farmers on black Sigatoka and its management in southern Benin. It came out that farmers' knowledge on the identification of black leaf spot is still limited in the various municipalities. Thus, the losses caused by this disease will continue to be a serious threat to the socioeconomic conditions of the households involved in plantain production as long as government policies do not promote this crop. In the current context, the poor proportion of farmers with limited knowledge of the disease, its incidence and management methods do not yet make it possible to immediately initiate training by peers. It is advisable to first test this knowledge in a practical way, to enlist other farmers in specific training sessions in order to build up their capacity before moving to scale with learning programme in the various municipalities. The "Farmer Field School" approach could be appropriate to achieve this relevant objective in order to reduce significantly the losses incurred due to the negative effects of black Sigatoka on yields. Farmer mastery of the means of dissemination of the pathogen is crucial in the successful management of this disease. Therefore, their awareness must be raised up on strategies and good practices to be implemented to reduce inoculum at the regional level, or maybe, at the municipality level. Multistakeholder management must be appropriate, since it will involve policy makers, researchers, farmers, NGOs and private actors through mechanisms and measures accessible to communities. 


\section{Acknowledgements}

This research was carried out with the financial support of the Dutch Organization for Scientific Research "NWOWOTRO" within the framework of the AVLANTO-Benin project, entitled "Strategic Diffusion and marketing of promising plantain varieties in Benin". The "Agence Universitaire de la Francophonie (AUF)" also supported financially this study.

\section{References}

[1] Norgrove, L., Hauser, S., 2014. Improving plantain (Musa spp. AAB) yields on smallholder farms in West and Central Africa, Food Secur., vol. 6, no. 4, pp. 501-514.

[2] Tripathi, J., Lorenzen, J., Bahar, O., Ronald, P., Tripathi, L., 2014. Transgenic expression of the rice Xa 21 patternrecognition receptor in banana (Musa sp.) confers resistance to Xanthomonas campestris pv. musacearum, Plant Biotechnol. $J$., vol. 12 , no. 6 , pp. 663-673.

[3] Honfo, G. F., Kayodé, A. P. P., Coulibaly, O., Tenkouano, A., 2007. Relative contribution of banana and plantain products to the nutritional requirements for iron, zinc and vitamin $\mathrm{A}$ of infants and mothers in Cameroon, Fruits, vol. 62, no. 5, pp. 371-377.

[4] Adepoju, O. T., Sunday, B. E., Folaranmi O. A., 2012. Nutrient composition and contribution of plantain (Musa paradisiacea) products to dietary diversity of Nigerian consumers, African $J$. Biotechnol., vol. 11, no. 71. pp. 13601-13605.

[5] Banful, B., Dzietror, A., Ofori, I., Hemeng, O. B., 2000. Yield of plantain alley cropped with Leucaena leucocephala and Flemingia macrophylla in Kumasi, Ghana, Agrofor. Syst., vol. 49, no. 2, pp. 189-199.

[6] Dzomeku, B. M., Dankyi, A. A., Darkey, S. K., 2011. Socioeconomic importance of plantain cultivation in Ghana, $J$. Anim. Plant Sci, vol. 21, no. 2, pp. 269-273.

[7] Aba, S. C., Baiyeri, K. P., 2015. Nitrogen and potassium fertilizer influenced nutrient use efficiency and biomass yield of two plantain (Musa spp. AAB) genotypes, African J. Agric. Res., vol. 10, no. 6, pp. 458-471.

[8] Depigny, S., Tchotang, F., Talla, M., Fofack, D., Essome, D., Ebongue, J-P., Kengni, B., Lescot, T., 2018. The "PlantainOptim'dataset: Agronomic traits of 405 plantains every 15 days from planting to harvest," Data Br., vol. 17, pp. 671-680.

[9] Jones, D. R., 2009. Disease and pest constraints to banana production," Acta Hortic., vol. 828, pp. 21-36.

[10] Osei, K., Mintah, P., Dzomeku, B. M., Braimah, H., Adomako, J., Mochiah, M. B., Asiedu, E., Darkey, S., Danso, Y., 2013. Nematode pests of plantain: A case study of Ashanti and Brong Ahafo regions of Ghana, J. Soil Sci. Environ. Manag., vol. 4, no. 1, pp. 6-10.

[11] Tripathi, L., Babirye, A., Roderick, H., Tripathi, J. N., Changa, C., Urwin, P. E., Tushemereirwe W. K., Coyne, D., Atkinson, H. J., 2013. Field resistance of transgenic plantain to nematodes has potential for future African food security, Sci. Rep., vol. 5, pp. 1-10.

[12] Kumar, P. L., Selvarajan, R., Iskra-Caruana, M. L.,
Chabannes, M., Hanna, R., 2015. Biology, etiology, and control of virus diseases of banana and plantain, Adv. Virus Res., vol. 91, no. 1, pp. 229-269.

[13] Orluchukwu, J. A., Ogburia, M. N., 2014. Introgression of bsr Gene from Wild 2n Accessions and Derivative Hybrids to Cultivated Landraces of Plantains (Musa Sp.), Int. J. Plant Res., vol. 4, no. 1, pp. 1-4.

[14] Castelan, F. P., Saraiva, L. A., Lange, F., de Lapeyre de Bellaire, L., Cordenunsi, B. R., Chillet, M., 2012. Effects of Black Leaf Streak Disease and Sigatoka Disease on fruit quality and maturation process of bananas produced in the subtropical conditions of southern Brazil, Crop Prot., vol. 35, pp. 127-131.

[15] Seydou, T., Amari, L-N. D. G. E., Chérif, M., Ouédraogo, S. L, Kassi, F., Kouamé, K. G., Camara, B., Koné, D., 2017. Agronomic Performance of Plantain Cultivars (Musa spp.) in Efficient Mixing Situation for the Control of Black Sigatoka in Southern Côte d'Ivoire, Asian J. Plant Pathol., vol. 11, no. 1, pp. 1-9.

[16] Chillet, M., Abadie, C., Hubert, O., Chilin-Charles, Y., de Lapeyre de Bellaire, L., 2009. Sigatoka disease reduces the greenlife of bananas, Crop Prot., vol. 28, no. 1, pp. 41-45.

[17] Ngando Essoh Otto, J., 2014. Sélection et évolution de la résistance aux fongicides systémiques chez Mycosphaerella fijiensis, agent causal de la maladie des raies noires des bananiers. Thèse de doctorat, Centre International d'Etudes Supérieures en Sciences Agronomiques, Montpellier. 144p.

[18] Kwa, M., Temple, L., 2019. Le bananier plantain: Enjeux socio-économiques et techniques, Quæ, CTA,. CTA, Postbus 380, 6700 AJ Wageningen, Pays-Bas.

[19] Traoré, S., Kobenan, K., Kouassi, K. S., Gnonhouri, G., 2009. Systèmes de culture du bananier plantain et méthodes de lutte contre les parasites et ravageurs en milieu paysan en Côte d'Ivoire, J. Appl. Biosci., vol. 19, pp. 1094-1101.

[20] Chabi, M. C., Dassou, A. G., Dossou-Aminon, I., Ogouchoro, D., Aman, B. O., Dansi, A., 2018. Banana and plantain production systems in Benin: Ethnobotanical investigation, varietal diversity, pests, and implications for better production, J. Ethnobiol. Ethnomed., vol. 14, no. 1, p.18.

[21] Lokossou, B., Affokpon, A., Adjanohoun, A., Dan C. B. S., Mensah, G. A., 2012. Evaluation des variables de croissance et de développement du bananier plantain en systèmes de culture associée au Sud-Bénin Bull. la Rech. Agron. du Bénin Numéro, pp. 10-17.

[22] Munyuli, T., Cihire, K., Rubabura, D., Mitima, K., Kalimba, Y., Tchombé, N., Mulangane, M. K., Birhashwira, O., Umoja, M., Cinyabuguma, E., Mukadi, T. T., Ilunga, M. T., Mukendi, R. T., 2017. Farmers' perceptions, believes, knowledge and management practices of potato pests in South-Kivu Province, eastern of Democratic Republic of Congo, Open Agric., vol. 2, no. 1 , pp. $362-385$.

[23] Tafesse, S., Damtew, E., van Mierlo, B., Lie, R., Lemaga, B., Sharma, K., Leeuwis, C., Struik, P. C., 2018. Farmers' knowledge and practices of potato disease management in Ethiopia, NJAS - Wageningen J. Life Sci., vol. 86-87, pp. 25-38.

[24] Machekano, H., Mvumi, B. M., Nyamukondiwa, C., 2020. Plutella xylostella (L.): pest status, control practices, perceptions and knowledge on existing and alternative management options in arid small-scale farming environments, Int. J. Pest Manag., vol. 66, no. 1, pp. 48-64. 
[25] Akutse, K. S., Owusu, E. O., Afreh-Nuamah, K., 2012. Perception of farmers' management strategies for termites control in Ghana, J. Appl. Biosci., vol. 49, pp. 3394-3405.

[26] Olaniran, O. A., Babarinde, S. A., Odewole, A. F., Aremu, P. A., Popoola, K., 2014. Rural farmers ' perceptions, knowledge and management of insect pests of fruit vegetables in Ogbomoso Agricultural Zone of Nigeria, Inter. Letters of NatSci, Vol. 20, pp. 18-28.

[27] Nagaraju, N., Venkatesh, H. M., Warburton, H., Muniyappa, V., Chancellor, T. C. B., Colvin, J., 2002. Farmers' perceptions and practices for managing tomato leaf curl virus disease in southern India, Int. J. Pest Manag., vol. 48, no. 4, pp. 333338 .

[28] Moinina, A., Lahlali, R., Maclean, D., Boulif, M., 2018. Farmers' knowledge, perception and practices in apple pest management and climate change in the fes-meknes region, Morocco, Horticulturae, vol. 4, 42; doi: 10.3390/horticulturae4040042.

[29] Uwamahoro, F., Berlin, A., Bucagu, C., Bylund, H., Yuen, J., 2018. Potato bacterial wilt in Rwanda: occurrence, risk factors, farmers' knowledge and attitudes, Food Secur, vol. 10 , no. 5 , pp. 1221-1235.

[30] Echodu, R., Edema, H., Wokorach, G., Zawedde, C., Otim, G., Luambano, N., Ateka E. M., Asiimwe, T., 2019. Farmers' practices and their knowledge of biotic constraints to sweetpotato production in East Africa, Physiol. Mol. Plant Pathol., vol. 105, pp. 3-16.

[31] Hountondji, Y-C., De Longueville, F., Ozer, P., 2011. Trends in extreme rainfall events in Benin (West Africa). 1960-2000., in The 1st International Conference on Energy. Environment And Climate Changes; Ho Chi Minh City. Vietnam, 12p.

[32] Schwartz, S. H., 1992. Universals in the content and structure of values: Theoretical advances and empirical tests in 20 countries. In M. P. Zanna (Ed.), Advances in experimental social psychology, Academic P., M. P. Zanna, Ed. San Diego, pp. 1-65.

[33] Hartemink, A. E., Johnston, M., O’sullivan, J. N., Poloma, S., 2000. Nitrogen use efficiency of taro and sweet potato in the humid lowlands of Papua New Guinea, Agric. Ecosyst. Environ., vol. 79, no. 2-3, pp. 271-280.

[34] R Core Team, 2020. A Language and Environment for Statistical Computing. R Foundation for Statistical Computing, [Online]. Available: https://www.r-project.org/. [Accessed: 30-May-2020].

[35] Wickham, H., 2016. ggplot2: Elegant Graphics for Data Analysis. New York: Springer-Verlag.

[36] Pérez-Vicente, L., 2012. A holistic integrated management approach to control Black Sigatoka Disease of banana caused by Mycosphaerella fijiensis," TCP/SLC/3402 Tech. Man., FOA, $30 \mathrm{p}$.

[37] Aho, N., Aho, S., Agbokou, I., Kaffo, B. A., Seni, S., Loconon, D. Z., 2018. Introduction à la résilience aux changements climatiques en Afrique de l'Ouest: Répertoire des dates prédéterminées des saisons pluvieuses dans les villages et quartiers de ville du Bénin. Ministère de l'Energie, de l'Eau et des Mines -PNUD Bénin, Cotonou.

[38] Ahanger, R. A., Bhat, H. A., Bhat, T. A., Ganie, S. A., Lone, A. A., Wani, I. A., Ganai, S. A., Haq, S., Khan, O. A., Junaid,
J. M., Bhat, T. A., 2013. Impact of climate change on plant pathogens, Int. J. Mod. Plant Anim. Sci., vol. 1, no. 3, pp. $105-115$.

[39] Rieux, A., Soubeyrand S., Bonnot, F., Klein E, K., Ngando J. E., Mehl, A., Ravigne, V., Carlier, J., de Lapeyre de Bellaire L., 2014. Long-distance wind-dispersal of spores in a fungal plant pathogen: Estimation of anisotropic dispersal kernels from an extensive field experiment, PLoS One, vol. 9, $\mathrm{n}^{\circ} 8$, doi: 10.1371/journal.pone.0103225.

[40] Robert, S., Ravigne, V., Zapater, M. F., Abadie, C., Carlier, J., 2012. Contrasting introduction scenarios among continents in the worldwide invasion of the banana fungal pathogen Mycosphaerella fijiensis, Mol. Ecol., vol. 21, no. 5, pp. 1098 1114.

[41] Amil, A. F., Heaney, S. P., Stanger, C., Shaw, M. W., 2007. Dynamics of QoI Sensitivity in Mycosphaerella fijiensis in Costa Rica During 2000 to 2003, vol. 97, no. 11, pp. 14511457.

[42] Islam, A. H. M. S., Schreinemachers, P., Kumar, S., 2020. Farmers' knowledge, perceptions and management of chili pepper anthracnose disease in Bangladesh, Crop Prot., vol. 133, p. 105139, doi.org/10.1016/j.cropro.2020.105139.

[43] Savary, S., Ficke, A., Aubertot, J. N., Hollier, C., 2012. Crop losses due to diseases and their implications for global food production losses and food security, Food Secur., vol. 4, no. 4, pp. 519-537.

[44] Akinro, A. O., Olufayo, A. A., Oguntunde, P. G., 2012. Crop Water Productivity of Plantain (Musa Sp) in a Humid Tropical Environment, J. Eng. Sci. Technol. Rev., vol. 5, no. 1, pp. 19-25.

[45] Tenkouano, A., Lamien, N., Agogbua, J., Amah, D., Swennen, R., Traoré, S., Thiemélé, D., Aby, N., Kobenan, K., Gnonhouri, G., Yao, N., Astin, G., Sawadogo-Kabore, S., Tarpaga, V., Issa, W., Lokossou, B., Adjanohoun, A., Amadji, G. L., Adangnitodé, S., Igue, K. A. D., Ortiz, R., 2019. Promising High-Yielding Tetraploid Plantain-Bred Hybrids in West Africa, Int. J. Agron., vol. 2019, doi.org/10.1155/2019/3873198.

[46] N'Guetta, A. N., Traore, S., Yao, N'-T., Aby, N., Koffi, Y. D., Atsin, G. O., Otro, S. T. V., Kobenan, K., Gnonhouri, P., YaoKouame, A., 2016. Incidence de la densité de plantation sur la croissance et le rendement du bananier plantain en Côte d' Ivoire: cas de deux hybrides (PITA 3 et FHIA 21) et deux variétés locales (Corne 1 et Orishele). Agronomie Africaine, vol. 27 , no. 3 , pp. 213-222.

[47] Barekye, A., Ruberintwari, H., Ssali R., Tushemereirwe, W. K., 2012. Sigatoka, and D. In, Selection of banana hybrids based on resistance to black sigatoka disease in Uganda. E. Afr. agric. For. J. vol. 78, pp. 84-88.

[48] Quain, M. D., Agyeman, A., Dzomeku, B. M., 2018. Assessment of plantain (Musa sapientum L.) accessions genotypic groups relatedness using simple sequence repeats markers," African J. Biotechnol., vol. 17, no. 16, pp. 541-551.

[49] Cavero, P. A. S., Hanada, R. E., Gasparotto, L., Neto, R. A. C., de Souza, J. T., 2015. Controle biológico da Sigatoka-negra da bananeira com Trichoderma, Cienc. Rural, vol. 45, no. 6, pp. 951-957.

[50] De Bellaire, L. D. L., Fouré, E., Abadie, C., Carlier, J., 2010. Black Leaf Streak Disease is challenging the banana industry," Fruits, vol. 65, no. 6, pp. 327-342. 
[51] Etebu, E., Wabiye, Y-H., 2011. Control of black sigatoka disease: Challenges and prospects, African J. Agric. Res., vol. 6, no. 3, pp. 508-514.

[52] Essis, B., Kobenan, K., Traoré, S., Koné, D., Yatty, J., 2010. Sensibilité au laboratoire de Mycosphaerella fijiensis responsable de la Cercosporiose noire des bananiers vis-à-vis de fongicides couramment utilisés dans les bananeraies ivoiriennes," J. Anim. Plant Sci., vol. 7, no. 2, pp. 822-833.
[53] Ganry, J., Foure, E., de Lapeyre de Bellaire, L., Lescot, T., 2012. An Integrated Approach to Control the Black Leaf Streak Disease (BLSD) of Bananas, while Reducing Fungicide Use and Environmental Impact," Fungic. Plant Anim. Dis., DOI: 10.5772/29794. 